\title{
MOLDOVAN EXTERNAL TRADE WITH EU, CIS AND OTHER COUNTRIES: ACHIEVEMENTS AND CHALLENGES
}

\section{Alexandru CEBAN ${ }^{1}$, PhD Student, Scientific Researcher, National Institute for Economic Research, Republic of Moldova}

The foreign trade of a state represents a determinant factor in assessing its economic statute among the neighbours and in the whole world. The actuality of the studied topic is determined by the changing trade relations that the Republic of Moldova is passing through in the last years. Republic of Moldova holds the necessary criteria for becoming a competitive country in the region in terms of the manufactured and marketed goods. The aim of the study is to evaluate the foreign trade of the Republic of Moldova, by emphasizing the main traded groups of products, trade partners as well as to analyze the average price index and physical volume index of imports and exports. The paper also comes with an analysis of re-export and re-import, which represents a peculiarity for our country's trade pattern. Research methods that have been used within the paper are the following: analogy, systemic approach, statistical and scientific analysis, Laspeyres index method. The obtained results focus on the recovery of the foreign trade between 2015 and 2017 with higher revival rates of exports, and a growing reorientation of exports towards the European Union and other countries' markets.

Keywords: import, export, foreign trade, economy, Republic of Moldova, average price index, physical volume index.

Comerțul exterior al unui stat reprezintă un factor determinant în evaluarea statutului său economic între vecini și celelalte state. Actualitatea temei studiate este determinată de schimbarea relațiilor comerciale pe care Republica Moldova le parcurge în ultimii ani. Republica Moldova posedă toate premisele necesare pentru a deveni o țară competitivă în regiune, prin prisma produselor fabricate și comercializate. Scopul studiului este de a evalua comerțul exterior al Republicii Moldova, accentuând principalele grupuri de produse tranzacționate, partenerii comerciali, precum și analiza indicelui mediu al prețurilor și indicelui volumului fizic al importurilor și exporturilor. În lucrare se regăsește, de asemenea, o analiză a reexportului și a reimportului, care reprezintă o particularitate pentru modelul comercial al țării noastre. Metodele de cercetare utilizate în cadrul lucrării sunt următoarele: analogie, abordare sistemică, analiză statistică și științifică, metoda indicelui Laspeyres. Rezultatele obținute se concentrează pe redresarea comerțului exterior între 2015 și 2017, cu rate mai mari de recuperare a exporturilor și o reorientare tot mai mare a exporturilor spre piețele Uniunii Europene și ale altor țări.

Cuvinte-cheie: import, export, comert exterior, economie, Republica Moldova, indicatori Laspeyres.

Внешняя торговля государства является определяющим фактором при оценке его экономического статуса среди соседей и других государств. Актуальность изучаемой темы определяется изменением торговых отношений, которое сложилось в Молдове за последние годы. Республика Молдова имеет все необходимые предпосылки для того, чтобы стать конкурентоспособной страной в регионе с точки зрения выпускаемой и продаваемой продукции. Целью исследования является оценка внешней торговли Республики Молдова, выделение основных групп реализуемой продукции, торговых партнеров, а также анализ индекса средних цен и индекса физического объема импорта и экспорта. В данной роботе также содержится обзор реэкспорта и реимпорта, который является особенностью коммерческой модели нашей страны. Методы исследования, используемые в статье: аналогия, системный подход, статистический и научный анализ, метод индекса Ласпейреса. Результаты сфокусированы на восстановлении внешней торговли между 2015 и 2017 годами, с более высокими темпами восстановления экспорта и растущей переориентацией экспорта на ЕС и другие рынки.

Ключевые слова: импорт, экспорт, внешняя торговля, экономика, Республика Молдова, показатели Ласпейреса.

DOI: https://doi.org/10.36004/nier.es.2019.1-04

JEL Classification: F10 UDC: 339.5(478:4)

1 ( ) Alexandru CEBAN, ceban_alexander@yahoo.com 
Introduction. The foreign trade of the Republic of Moldova has undergone some significant changes in the last seven years. Changing relations with CIS countries and signing of the DCFTA with EU represented the determinant factors for changing the vector of the external trade of the country. The trade pattern in terms of both, exports and imports, has changed during the recent years, showing a smaller degree of dependence on the "old" trade partners. Based on the applied research methods, this paper aims to present an analysis of the current situation of the Moldovan foreign trade, thus highlighting the groups of products mostly intended for export and import. The use of the Laspeyres index method allows us to evaluate the price index and physical volume index, thus determining the real physical volumes and the real price difference for certain products from the commodity groups. The issue of external trade and its impact on the economic development of a country, including the in depth analysis of the trade in term of Laspeyres index, has been studied by various foreign scholars, such as Pomfret R. (Pomfret, R. 2005), Lipsey R. (Lipsey, R., 1991), Helpman and Krugman (Helpman, E., Krugman, P. 1985), etc. Moldovan scientists that analyzed the external trade of the Republic of Moldova in a broad sense are the following: Stratan A. and Clipa V., (Stratan, A., Clipa V., 2011), Galben I., (Galben, I., 2012), Ganciucov V. and Ceban A. (Ganciucov, V., Ceban A. 2015), Ceban A. (Ceban, A. 2017) and others.

The given study is based primarily on analysis of statistical data on foreign trade provided by the National Bureau of Statistics and WITS database.

Applied research methods

For a better assessment of the current situation related to the external trade of the Republic of Moldova, the following research methods have been used: analogy, systemic approach, statistical analysis of the databases and scientific analysis of the used literature and methodology. At the same time, the author has used the Laspeyres index to measure the changes between two periods of time in the total cost of purchasing the basket of goods and services that is representative comparative to the base period.

The methodology has at least three practical advantages: it is easily explained to the public; it can make repeated use of the same data on consumer purchases; and it doesn't need to be revised, assuming that users are satisfied with the Laspeyres concept. Another notable advantage is that the Laspeyres is consistent in aggregation down to the lowest level of aggregation. (Consumer..., 2004, Ceban, A. 2017).

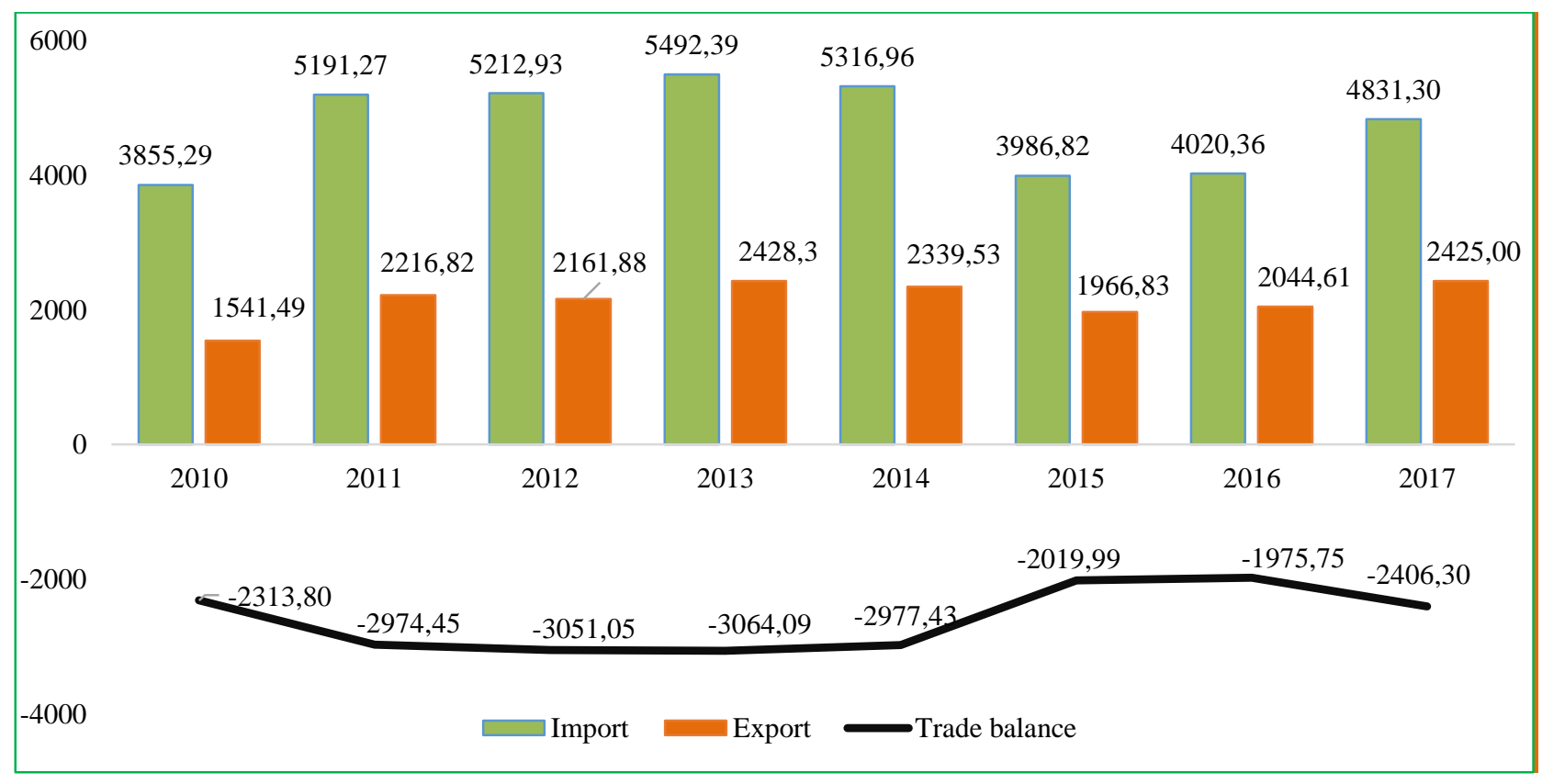

Figure 1. Trade balance of the Republic of Moldova, 2010 - 2017, mil. USD

Source: Elaborated by the author based on the data of the National Bureau of Statistics. 


\section{Results obtained}

During the period of 2010-2017 the balance of the foreign trade had experienced increasing as well as decreasing trends (Figure 1). This result is due both, to imports, which increased in 2011-2014 with maximum values in 2013, but which has diminished its value in the years 2015 and 2016 with a tendency to recover in 2017. The exports are following the import's trends, but in a slower way.

Although the export of manufactured goods in 2017 did not reach yet the value of 2013, it increased compared to 2010 by $25.3 \%$. Nevertheless, compared with the previous years of decline (2015 and 2016) the year of 2017 brought a growth of $18.6 \%$ compared to 2016, mainly due to the recovery of the banking sector after a crisis period of 2015-2016, increase in production of most of the commodities, as well as to the strengthening of the national currency. Cooperation with the EU countries, which accounted for $65.9 \%$ of total exports (Table 1), represented one of the main drivers of the above-mentioned increase. The import in 2017 reached a value of 4831.3 mil. USD, which accounted for a $20.2 \%$ increase compared to 2016 and $57.3 \%$ compared to 2010 . This result is largely due to imports from the European Union countries, which reached $49.5 \%$ of the total import in 2017.

Foreign trade of the Republic of Moldova in 2017

\begin{tabular}{|c|c|c|c|c|c|c|}
\hline \multirow{2}{*}{ Indicators } & \multicolumn{2}{|c|}{2017} & \multicolumn{2}{|c|}{ Structure \% } & \multicolumn{2}{|c|}{$\begin{array}{l}\text { The degree of influence on } \\
\text { the increase }(+) \text {, decrease }(-) \\
\text { of the indicators }\end{array}$} \\
\hline & mil. USD & $\begin{array}{l}\% \text { to } \\
\text { previous } \\
\text { year }\end{array}$ & 2016 & 2017 & 2016 & 2017 \\
\hline Total export, of which: & 2425 & 118.6 & 100 & 100 & 3.9 & 18.6 \\
\hline CIS countries & 462.8 & 111.8 & 20.3 & 19.1 & -3.9 & 2.3 \\
\hline EU countries & 1596.9 & 119.9 & 65.1 & 65.9 & 5.8 & 12.9 \\
\hline Other countries & 365.3 & 122.4 & 14.6 & 15.1 & 2.1 & 3.2 \\
\hline Total import, of which: & 4831.3 & 120.2 & 100 & 100 & 0.8 & 20.1 \\
\hline CIS countries & 1206 & 122.4 & 25.6 & 24.9 & 0.2 & 4.4 \\
\hline EU countries & 2389.2 & 121.1 & 49.1 & 49.5 & 0.4 & 10.3 \\
\hline Other countries & 1236.1 & 121.3 & 25.4 & 25.6 & 0.1 & 5.4 \\
\hline $\begin{array}{l}\text { Deficit of the trade balance, } \\
\text { of which: }\end{array}$ & -2406.3 & 121.8 & 100 & 100 & -2.1 & 21.7 \\
\hline CIS countries & -743.2 & 121.2 & 31.04 & 30.9 & 4.3 & 6.5 \\
\hline EU countries & -792.3 & 123.4 & 32.5 & 32.9 & -4.7 & 7.6 \\
\hline Other countries & -870.8 & 120.8 & 36.5 & 36.2 & -1.8 & 7.6 \\
\hline
\end{tabular}

Source: Elaborated by the author based on the data of the National Bureau of Statistics.

\section{Import}

After analyzing the imports during the period 2011-2017, one can note a stability over the period 2011-2014, which was followed by a significant reduction in 2015 and a slight increase in 2016, with signs of marked revival in 2017. This reduction was conditioned by several factors, including the reduction of remittances, the reduction of foreign direct investment and the massive elimination of capital by individuals and businesses as a result of the banking problems that took place during the recent years. However, structurally examining the import over the years, one can observe a reorientation from the CIS to the EU market. Thus, at the beginning of the analyzed period, imports from CIS countries had a share of 33\% of the total imports, and in 2017 they fell to a level similar to imports from other countries, accounting for about $25 \%$. EU imports in 2011 registered a $43.5 \%$ share, and over the years they strengthened their positions and in 2017 reached a $49.5 \%$ share of the total imports.

In 2017, the European Union, being the main trade economic partner, exported in the Republic of Moldova commodities valued at 2389.2 mil. USD, marking an increase of $21.1 \%$ compared to the previous year. The main import partners of the Republic of Moldova in the European Union are Romania, Germany, Italy, Poland and France. Altogether these five counties accounted for $68.2 \%$ of total imports in 2011 and $70.9 \%$ in 2017 registering an increase of $2.7 \%$. 


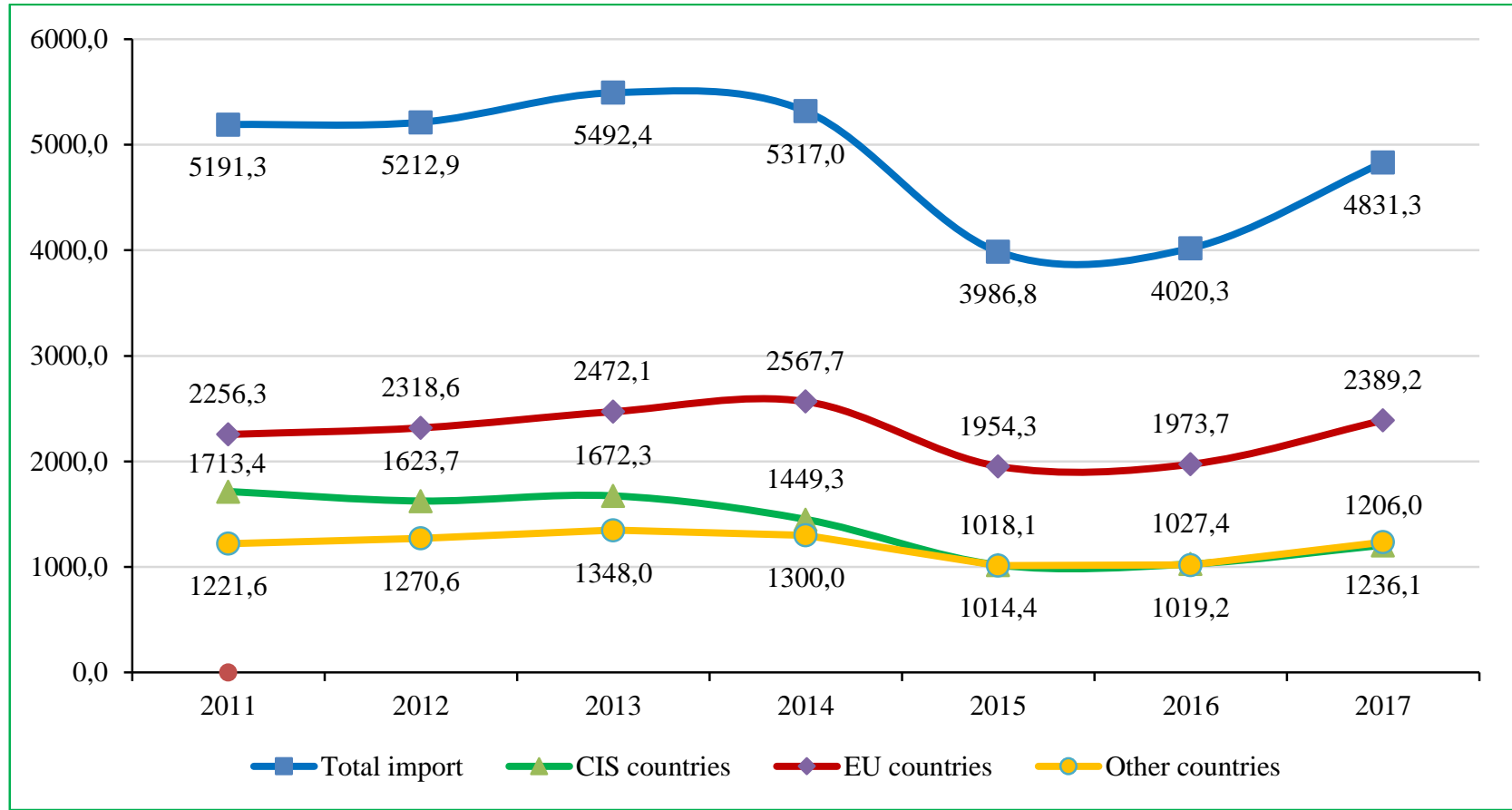

Figure 2. Dynamics of imported goods, 2010-2017, mil. USD

Source: Elaborated by the author based on the National Bureau of Statistics data.

Imports from CIS countries also registered an increase in 2017, accounting for $22.4 \%$ compared to the previous year. Among the CIS countries, the main import partners for the Republic of Moldova between 2011 and 2017 were the Russian Federation, Ukraine, Belarus, Uzbekistan and Kazakhstan, which covered virtually all imports from CIS countries over the analysed period or $99.2 \%$ in 2011 and $99.9 \%$ in 2017.

In terms of the import from the category of "Other countries", which marked an increase of 21.3\% compared to 2016 (1236.1 mil. USD), the main import partners are China, Turkey, USA, Vietnam and Japan. Their share in 2011 accounted for $74.3 \%$, and in 2017 they strengthened their positions to a share of $77.3 \%$ of the total imports from other countries.

Overall, the first 15 countries that export goods to the Republic of Moldova hold a share of $84.7 \%$ of the total import.

The main 5 groups of commodities, which according to the Commodity Nomenclature for 2017 accounted for $60 \%$ of the total imported goods are the following: "Machinery and mechanical appliances; electrical equipment; parts thereof; sound recorders and reproducers, television image and sound recorders and reproducers, and parts and accessories of such articles", "Mineral products", "Products of the chemical or allied industries", "Textiles and textile articles", "Prepared foodstuffs; beverages, spirits and vinegar; tobacco and manufactured tobacco substitutes".

Table 2

The most important 15 import countries

\begin{tabular}{|c|c|c|c|c|c|c|}
\hline \multirow[t]{2}{*}{ Country name } & \multicolumn{2}{|c|}{ Import 2017} & \multicolumn{2}{|c|}{ Structure \% } & \multicolumn{2}{|c|}{$\begin{array}{c}\text { The degree of } \\
\text { influence on the } \\
\text { increase }(+) \text {, decrease } \\
(-) \text { of exports }\end{array}$} \\
\hline & Total, mil. USD & $\%$ to previous year & 2016 & 2017 & 2016 & 2017 \\
\hline Total & 4831.4 & 120.2 & 100 & 100 & 0.8 & 20.17 \\
\hline Romania & 694.51 & 125.9 & 13.7 & 14.4 & -0.1 & 3.5 \\
\hline Russian Federation & 571.7 & 106.8 & 13.3 & 11.8 & -0.01 & 0.9 \\
\hline Ukraine & 511.1 & 133.1 & 9.6 & 10.6 & 0.3 & 3.1 \\
\hline China & 505.4 & 128.4 & 9.8 & 10.5 & 0.6 & 2.7 \\
\hline Germany & 390.6 & 123.4 & 7.9 & 8.1 & -0.1 & 1.8 \\
\hline
\end{tabular}




\begin{tabular}{|c|c|c|c|c|c|c|}
\hline \multirow[t]{2}{*}{ Country name } & \multicolumn{2}{|c|}{ Import 2017} & \multicolumn{2}{|c|}{ Structure \% } & \multicolumn{2}{|c|}{$\begin{array}{c}\text { The degree of } \\
\text { influence on the } \\
\text { increase }(+) \text {, decrease } \\
(-) \text { of exports }\end{array}$} \\
\hline & Total, mil. USD & $\%$ to previous year & 2016 & 2017 & 2016 & 2017 \\
\hline Italy & 331.3 & 118.0 & 7.0 & 6.9 & 0.04 & 1.2 \\
\hline Turkey & 304.3 & 111.9 & 6.8 & 6.3 & -0.3 & 0.8 \\
\hline Poland & 165.7 & 125.4 & 3.3 & 3.4 & 0.2 & 0.8 \\
\hline Belarus & 114.6 & 113.1 & 2.5 & 2.4 & 0.4 & 0.3 \\
\hline France & 112.7 & 125.3 & 2.2 & 2.3 & 0.2 & 0.5 \\
\hline Hungary & 99.6 & 124.4 & 2.0 & 2.1 & 0.2 & 0.4 \\
\hline Austria & 80.3 & 108.9 & 1.8 & 1.7 & -0.4 & 0.1 \\
\hline Bulgaria & 74.1 & 128.6 & 1.4 & 1.5 & -0.2 & 0.4 \\
\hline USA & 70.2 & 131.8 & 1.3 & 1.5 & 0.06 & 0.4 \\
\hline Czech Republic & 68.2 & 121.5 & 1.4 & 1.4 & 0.1 & 0.3 \\
\hline
\end{tabular}

Source: Elaborated by the author based on the data of the National Bureau of Statistics.

The explanation of the high import values for the first three groups of products mentioned above comes from the very moderate level of production registered in the Republic of Moldova, as well as from the population and market oriented towards "consumption" of the commodities from these groups.

Textiles are imported as a raw material and due to investments made by foreign entrepreneurs in the textile industry are processed and further exported under the form of clothes and articles of thereof.

As for the group of "Prepared foodstuff" tobacco, spirits and prepared food products have the greatest values of total imports in this group.

Import by group of goods structured by value, mil. USD

\begin{tabular}{|c|c|c|c|c|c|c|}
\hline \multirow{2}{*}{ Code } & \multirow{2}{*}{ Name of the commodity group } & \multicolumn{2}{|r|}{2017} & \multicolumn{2}{|c|}{ Structure \% } & \multirow{2}{*}{$\begin{array}{c}\begin{array}{c}\text { Structural } \\
\text { changes, } \\
\text { p.p. }\end{array} \\
2017\end{array}$} \\
\hline & & mil. USD & $\%$ to previous year & 2016 & 2017 & \\
\hline & Total import & 4831.3 & 120.1 & 100.0 & 100.0 & $\mathrm{X}$ \\
\hline XVI. & $\begin{array}{l}\text { Machinery and mechanical appliances; } \\
\text { electrical equipment; parts thereof; } \\
\text { sound recorders and reproducers, } \\
\text { television image and sound recorders } \\
\text { and reproducers, and parts and } \\
\text { accessories of such articles }\end{array}$ & 801.2 & 124.5 & 16.0 & 16.5 & 0.5 \\
\hline V. & Mineral products & 774.2 & 122.8 & 15.6 & 16.0 & 0.3 \\
\hline VI. & $\begin{array}{l}\text { Products of the chemical or allied } \\
\text { industries }\end{array}$ & 572.9 & 113.9 & 12.5 & 11.8 & -0.6 \\
\hline XI. & Textiles and textile articles & 398.3 & 115.2 & 8.6 & 8.2 & -0.3 \\
\hline IV. & $\begin{array}{l}\text { Prepared foodstuffs; beverages, } \\
\text { spirits and vinegar; tobacco and } \\
\text { manufactured tobacco substitutes }\end{array}$ & 352.8 & 115.6 & 7.5 & 7.3 & -0.2 \\
\hline $\mathrm{XV}$. & Base metals and articles of base metal & 343.9 & 125.5 & 6.8 & 7.1 & 0.3 \\
\hline XVII. & $\begin{array}{l}\text { Vehicles, aircraft, vessels and } \\
\text { associated transport equipment }\end{array}$ & 294.6 & 126.8 & 5.7 & 6.1 & 0.3 \\
\hline VII. & $\begin{array}{l}\text { Plastics and articles thereof; rubber } \\
\text { and articles thereof }\end{array}$ & 292.2 & 113.3 & 6.4 & 6.0 & -0.3 \\
\hline II. & Vegetable products & 195.3. & 113.7 & 4.2 & 4.0 & -0.2 \\
\hline $\mathrm{XX}$. & Miscellaneous manufactured articles & 138.0 & 119.7 & 2.8 & 2.8 & -0.01 \\
\hline I. & Live animals; animal products & 131.5 & 122.9 & 2.6 & 2.7 & 0.06 \\
\hline
\end{tabular}

No. $1 / 2019$ 


\begin{tabular}{|c|c|c|c|c|c|c|}
\hline XIII. & $\begin{array}{l}\text { Articles of stone, plaster, cement, } \\
\text { asbestos, mica or similar materials; } \\
\text { ceramic products; glass and } \\
\text { glassware }\end{array}$ & 122.5 & 118.1 & 2.5 & 2.5 & -0.04 \\
\hline IX. & $\begin{array}{l}\text { Wood and articles of wood; wood } \\
\text { charcoal; cork and articles of cork; } \\
\text { manufactures of straw, of esparto or } \\
\text { of other plaiting materials; } \\
\text { basketware and wickerwork }\end{array}$ & 105.8 & 124.1 & 2.1 & 2.1 & 0.07 \\
\hline X. & $\begin{array}{l}\text { Pulp of wood or of other fibrous } \\
\text { cellulosic material; waste and scrap } \\
\text { of paper or paperboard; paper and } \\
\text { paperboard and articles thereof }\end{array}$ & 88.0 & 112.1 & 1.9 & 1.8 & -0.1 \\
\hline XVIII. & $\begin{array}{l}\text { Optical, photographic, } \\
\text { cinematographic, measuring, } \\
\text { checking, precision, medical or } \\
\text { surgical instruments and apparatus; } \\
\text { clocks and watches; musical } \\
\text { instruments; parts and accessories } \\
\text { thereof }\end{array}$ & 76.0 & 133.8 & 1.4 & 1.5 & 0.2 \\
\hline VIII. & $\begin{array}{l}\text { Raw hides and skins, leather, furskins } \\
\text { and articles thereof; saddlery and } \\
\text { harness; travel goods, handbags and } \\
\text { similar containers; articles of animal } \\
\text { gut (other than silkworm gut) }\end{array}$ & 64.6 & 133.4 & 1.2 & 1.3 & 0.1 \\
\hline XII. & $\begin{array}{l}\text { Footwear, headgear, umbrellas, sun } \\
\text { umbrellas, walking-sticks, seat-sticks, } \\
\text { whips, riding-crops and parts thereof; } \\
\text { prepared feathers and articles made } \\
\text { therewith; artificial flowers; articles } \\
\text { of human hair }\end{array}$ & 43.9 & 160.8 & 0.6 & 0.9 & 0.2 \\
\hline III. & $\begin{array}{l}\text { Animal or vegetable fats and oils and } \\
\text { their cleavage products; prepared } \\
\text { edible fats; animal or vegetable } \\
\text { waxes }\end{array}$ & 25.7 & 105.4 & 0.6 & 0.5 & -0.07 \\
\hline XIV. & $\begin{array}{l}\text { Natural or cultured pearls, precious } \\
\text { or semi-precious stones, precious } \\
\text { metals, metals clad with precious } \\
\text { metal and articles thereof; imitation } \\
\text { jewellery; coin }\end{array}$ & 8.8 & 120.0 & 0.1 & 0.1 & 0.00 \\
\hline XXI. & $\begin{array}{l}\text { Works of art, collectors pieces and } \\
\text { antiques }\end{array}$ & 1.1 & 27.9 & 0.1 & 0.0 & -0.08 \\
\hline
\end{tabular}

Source: Elaborated by the author based on the National Bureau of Statistics data.

During the period of 2011-2013, the most important group of products was "Mineral Products". Since 2013 it has been in a continuous decline, with little attempts to restore the situation. In 2017 it decreased by $38.39 \%$ compared to 2013 , being overtaken by the group "Machinery and mechanical appliances; electrical equipment; parts thereof; sound recorders and reproducers, television image and sound recorders and reproducers, and parts and accessories of such articles". This significant reduction of the Mineral products group is largely due to reductions occurred in its subgroup, namely the "Mineral fuels, mineral oils and products from distillation; bituminous materials; mineral wax", which has a share of about $98 \%$ of the given group over the last years and which also decreased in 2017 by $38.42 \%$ compared to 2013 .

The most significant increases in 2017 compared to the previous year were recorded within the groups "Footwear, headgear, umbrellas, sun umbrellas, walking-sticks, seat-sticks, whips, ridingcrops and parts thereof; prepared feathers and articles made therewith; artificial flowers; articles of human hair", "Optical, photographic, cinematographic, measuring, checking, precision, medical or 
surgical instruments and apparatus; clocks and watches; musical instruments; parts and accessories thereof", "Raw hides and skins, natural fur and articles thereof", "Vehicles, aircraft, vessels and associated transport equipment" and "Base metals and articles of base metal".

\section{Re-import}

During 2011-2017, there were no significant changes in the re-imported products. Thus, the share of re-importations in the total imports in this period is insignificant, varying between 0.1 and $0.3 \%$. In 2017 this indicator registered the value of $0.1 \%$.

\section{Export}

Analyzing the evolution of exports during the years 2011-2017 (Figure 3), we observe that although the total export has an oscillatory value with a maximum value in 2013 and tendencies of return in 2017, during the given period there is noted the reorientation of the export direction from the market of CIS countries to the EU market. Thus, if the export to the CIS countries in 2011 had a share of $41.5 \%$, it decreased to a share of $19.1 \%$ in 2017 . On the other hand, exports to the EU countries in 2011 recorded $48.9 \%$, marking an increase in the following years in percentage terms, reaching $65.9 \%$ of the total exports in 2017. It is also worth noting the increase in exports to other countries of the world from $9.7 \%$ in 2011 to $15.1 \%$ in 2017.

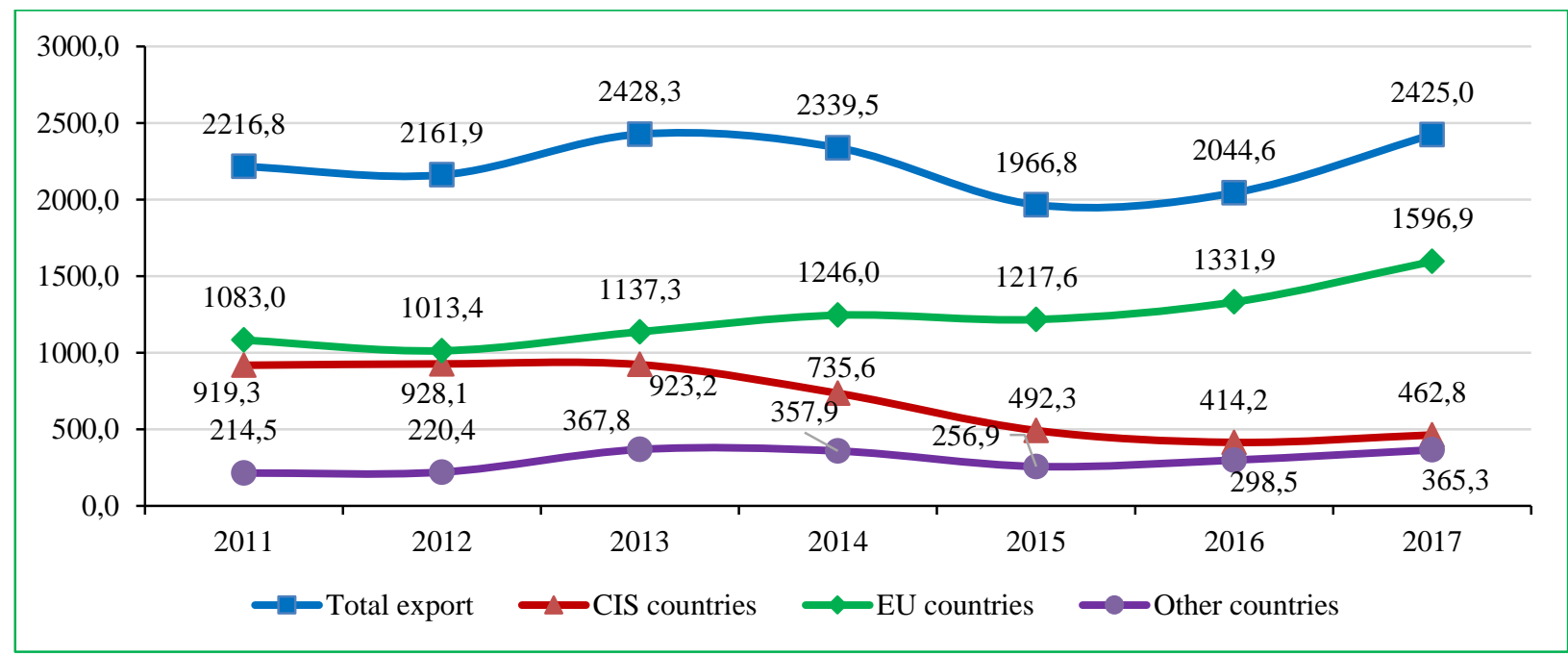

Figure 3. Total export of goods in 2011-2017, mil. USD

Source: Elaborated by the author based on the National Bureau of Statistics data.

The first 15 countries that import goods from the Republic of Moldova account for a share of $84.5 \%$ of the total Moldovan exports (Table 4).

Although the exports from the EU countries increased in 2017 by $19.9 \%$ compared to the previous year (1596.9 mil. USD), the trade balance still remains negative, as for the other groups of countries. On the European market, the main importing countries of the local products are Romania, which in the last years intensified its cooperation with the domestic producers, thus reaching 37.6\% of the total exports to the EU countries in 2017, followed by Italy, Germany, the Great Britain and Poland, which together make up about $77.7 \%$ of all consumers of Moldovan products.

Exports in CIS countries also recorded increased values, by $11.8 \%$ in 2017 compared to 2016 (462.8 mil. USD), the main consumer of domestic products being the Russian Federation, which, however, over the years 2011-2017 is gradually losing its positions. Thus, if in 2011 Russian Federation held a share of $68 \%$, then in 2017 this figure accounted for $54.9 \%$ of the total exports oriented towards the CIS market, being followed by Belarus, Ukraine, Georgia and Kazakhstan.

Exports to other countries (besides EU and CIS) has recorded the biggest increase (22.4\%) compared to 2016. In terms of exports, the leader to other countries over the years 2011-2017 remained Turkey. Although the share of exports in these directions has increased significantly, Turkey has substantially lost its position - from $34.2 \%$ in 2011 to $8.54 \%$ in 2017, followed by China, United States, Georgia and Iraq, which together account for $27.44 \%$ of total exports to other countries. 
Carrying out an analysis of exports by countries without taking into consideration the destination market, one can notice that over the years the leader in this ranking, until 2014 was the Russian Federation, which due to the embargo imposed for Moldova, was overtaken by Romania, which is strengthening its position in the standings during the last years (Ceban, A., 2017). Italy, Germany, the United Kingdom and Belarus are the next countries in this ranking, which throughout the 2011-2017 period remained almost unchanged. These countries in 2017 hold a share of $62 \%$ of the total exports of the Republic of Moldova.

Table 4

The most important 15 export countries

\begin{tabular}{|c|c|c|c|c|c|c|c|}
\hline & \multirow[t]{2}{*}{ Country name } & \multicolumn{2}{|c|}{ Export in 2017} & \multicolumn{2}{|c|}{ Structure \% } & \multicolumn{2}{|c|}{$\begin{array}{l}\text { The degree of } \\
\text { influence on the } \\
\text { increase }(+), \\
\text { decrease }(-) \text { of } \\
\text { exports }\end{array}$} \\
\hline & & Total, mil. USD & $\%$ to previous year & 2016 & 2017 & 2016 & 2017 \\
\hline & Total export & 2425.0 & 118.6 & 100 & 100 & 4.0 & 18.6 \\
\hline 1 & Romania & 600.6 & 117.1 & 25.1 & 24.7 & 3.4 & 4.3 \\
\hline 2 & Russian Federation & 254.5 & 109.1 & 11.4 & 10.5 & -0.4 & 1.0 \\
\hline 3 & Italy & 236.0 & 119.3 & 9.7 & 9.7 & 0.0 & 1.9 \\
\hline 4 & Germany & 166.1 & 131.2 & 6.2 & 6.8 & 0.5 & 1.9 \\
\hline 5 & Great Britain & 136.1 & 119.1 & 5.6 & 5.6 & -1.2 & 1.1 \\
\hline 6 & Belarus & 110.0 & 106.3 & 5.1 & 4.5 & -1.4 & 0.3 \\
\hline 7 & Turkey & 104.0 & 169.2 & 3.0 & 4.2 & -0.1 & 2.1 \\
\hline 8 & Poland & 102.9 & 140.2 & 3.6 & 4.2 & 0.3 & 1.4 \\
\hline 9 & Bulgaria & 78.1 & 102.7 & 3.7 & 3.2 & 2.4 & 0.1 \\
\hline 10 & Ukraine & 65.5 & 131.8 & 2.4 & 2.7 & 0.2 & 0.8 \\
\hline 11 & France & 50.8 & 113.6 & 2.2 & 2.1 & 0.1 & 0.3 \\
\hline 12 & Switzerland & 44.0 & 99.0 & 2.2 & 1.8 & 0.5 & 0.0 \\
\hline 13 & Austria & 40.8 & 150.0 & 1.3 & 1.6 & 0.3 & 0.7 \\
\hline 14 & Czech Republic & 29.8 & 105.6 & 1.3 & 1.2 & 0.0 & 0.1 \\
\hline 15 & Greece & 29.4 & 100 & 1.4 & 1.2 & 0.2 & 0.0 \\
\hline
\end{tabular}

Source: Elaborated by the author based on the data of the National Bureau of Statistics.

The most exported commodity groups according to the Combined Nomenclature of Goods are the following: "Vegetable products", which hold $27.31 \%$ of the total exported goods, followed by "Machines and apparatus, electrical equipment and parts thereof; sound recorders and reproducers, television image and sound recorders or reproducers, and parts and accessories of such apparatus", "Prepared foodstuffs; beverages, spirits and vinegar; tobacco and manufactured tobacco substitutes", "Textiles and textile articles" and "Miscellaneous manufactured articles". The monetary value and weight of these products in the total exported goods as compared to 2016 increased, reaching a share of $79.2 \%$ in 2017.

Export of the Republic of Moldova divided by groups of goods, 2016-2017

\begin{tabular}{|c|c|c|c|c|c|c|}
\hline \multirow{2}{*}{ Code } & \multirow{2}{*}{ Name of the commodity group } & \multicolumn{2}{|r|}{2017} & \multicolumn{2}{|c|}{ Structure \% } & \multirow{2}{*}{$\begin{array}{c}\begin{array}{c}\text { Structural } \\
\text { changes, p.p }\end{array} \\
2017\end{array}$} \\
\hline & & $\begin{array}{l}\text { mil. } \\
\text { USD }\end{array}$ & $\begin{array}{c}\% \text { to previous } \\
\text { year }\end{array}$ & 2016 & 2017 & \\
\hline I & Live animals; animal products & 47.1 & 117.2 & 1.9 & 1.9 & -0.02 \\
\hline II & Vegetable products & 662.5 & 125.1 & 25.9 & 27.3 & 1.4 \\
\hline III & $\begin{array}{l}\text { Animal or vegetable fats and oils and their } \\
\text { cleavage products; prepared edible fats; } \\
\text { animal or vegetable waxes }\end{array}$ & 53.7 & 98.9 & 2.6 & 2.2 & -0.4 \\
\hline
\end{tabular}




\begin{tabular}{|c|c|c|c|c|c|c|}
\hline \multirow{2}{*}{ Code } & \multirow{2}{*}{ Name of the commodity group } & \multicolumn{2}{|r|}{2017} & \multicolumn{2}{|c|}{ Structure \% } & \multirow{2}{*}{$\begin{array}{c}\begin{array}{c}\text { Structural } \\
\text { changes, p.p. }\end{array} \\
2017\end{array}$} \\
\hline & & $\begin{array}{l}\text { mil. } \\
\text { USD }\end{array}$ & $\begin{array}{l}\% \text { to previous } \\
\text { year }\end{array}$ & 2016 & 2017 & \\
\hline IV & $\begin{array}{l}\text { Prepared foodstuffs; beverages, spirits and } \\
\text { vinegar; tobacco and manufactured tobacco } \\
\text { substitutes }\end{array}$ & 367.7 & 114.3 & 15.7 & 15.1 & -0.5 \\
\hline $\mathrm{V}$ & Mineral products & 28.7 & 201.3 & 0.7 & 1.1 & 0.5 \\
\hline VI & Products of the chemical or allied industries & 98.7 & 109.1 & 4.4 & 4.0 & -0.34 \\
\hline VII & $\begin{array}{l}\text { Plastics and articles thereof; rubber and } \\
\text { articles thereof }\end{array}$ & 33.4 & 93.6 & 1.7 & 1.3 & -0.4 \\
\hline VIII & $\begin{array}{l}\text { Raw hides and skins, leather, furskins and } \\
\text { articles thereof; saddlery and harness; travel } \\
\text { goods, handbags and similar containers; } \\
\text { articles of animal gut (other than silkworm } \\
\text { gut) }\end{array}$ & 20.8 & 87.1 & 1.2 & 0.8 & -0.3 \\
\hline IX & $\begin{array}{l}\text { Wood and articles of wood; wood charcoal; } \\
\text { cork and articles of cork; manufactures of } \\
\text { straw, of esparto or of other plaiting } \\
\text { materials; basketware and wickerwork }\end{array}$ & 10.5 & 108.8 & 0.4 & 0.4 & -0.04 \\
\hline $\mathrm{X}$ & $\begin{array}{l}\text { Pulp of wood or of other fibrous cellulosic } \\
\text { material; waste and scrap of paper or } \\
\text { paperboard; paper and paperboard and } \\
\text { articles thereof }\end{array}$ & 13.2 & 107.9 & 0.6 & 0.5 & -0.05 \\
\hline $\mathrm{XI}$ & Textiles and textile articles & 346.7 & 112.8 & 15.0 & 14.3 & -0.7 \\
\hline XII & $\begin{array}{l}\text { Footwear, headgear, umbrellas, sun } \\
\text { umbrellas, walking-sticks, seat-sticks, whips, } \\
\text { riding-crops and parts thereof; prepared } \\
\text { feathers and articles made therewith; } \\
\text { artificial flowers; articles of human hair }\end{array}$ & 34.0 & 115.8 & 1.4 & 1.4 & -0.03 \\
\hline XIII & $\begin{array}{l}\text { Articles of stone, plaster, cement, asbestos, } \\
\text { mica or similar materials; ceramic products; } \\
\text { glass and glassware }\end{array}$ & 42.1 & 94.9 & 2.2 & 1.7 & -0.4 \\
\hline XIV & $\begin{array}{l}\text { Natural or cultured pearls, precious or semi- } \\
\text { precious stones, precious metals, metals clad } \\
\text { with precious metal and articles thereof; } \\
\text { imitation jewellery; coin }\end{array}$ & 1.2 & 160.1 & 0.04 & 0.05 & 0.01 \\
\hline $\mathrm{XV}$ & Base metals and articles of base metal & 48.3 & 111.0 & 2.1 & 1.9 & -0.1 \\
\hline XVI & $\begin{array}{l}\text { Machinery and mechanical appliances; } \\
\text { electrical equipment; parts thereof; sound } \\
\text { recorders and reproducers, television image } \\
\text { and sound recorders and reproducers, and } \\
\text { parts and accessories of such articles }\end{array}$ & 389.6 & 130.9 & 14.5 & 16.0 & 1.5 \\
\hline XVII & $\begin{array}{l}\text { Vehicles, aircraft, vessels and associated } \\
\text { transport equipment }\end{array}$ & 41.4 & 150.6 & 1.3 & 1.7 & 0.4 \\
\hline XVIII & $\begin{array}{l}\text { Optical, photographic, cinematographic, } \\
\text { measuring, checking, precision, medical or } \\
\text { surgical instruments and apparatus; clocks } \\
\text { and watches; musical instruments; parts and } \\
\text { accessories thereof }\end{array}$ & 30.8 & 106.7 & 1.4 & 1.3 & -0.1 \\
\hline $\mathrm{XX}$ & Miscellaneous manufactured articles & 154.6 & 115.4 & 6.5 & 6.4 & -0.2 \\
\hline XXI & Works of art, collectors pieces and antiques & 0.0 & 28.9 & 0.0 & 0.0 & 0.0 \\
\hline
\end{tabular}

Source: Elaborated by the author based on the data of the National Bureau of Statistics.

Analyzing the exports between 2010 and 2017, we can observe the considerable weight of the agri-food products. Thus, in 2010, the share of these products accounted for $47.5 \%$ of the total exported goods. Although the percentage share in 2011-2014 is decreasing, in the following period 2014-2015 it increases significantly in monetary values compared to the previous period. In the same time, it increased on average for the years 2015-2017, keeping the same share in the total exported goods. 
The agricultural sector of the Republic of Moldova holds a significant importance in the country's economy. With a share of about $12 \%$ in GDP in the last years, it has a high degree of influence over the exports of the country. Exports of vegetable products record high values mainly due to the export of low added value cultures such as cereals (wheat, sunflower and maize), and vegetables and fruits. Therefore, in order to increase the sector's competitiveness on the foreign markets, it is necessary to make investments along the most important value chain for each sector, so that the processed products would bring added value to the sector.

Table 6

Dynamics of export of agri-food goods, 2010-2017, mil. USD

\begin{tabular}{|c|l|c|c|c|c|c|c|c|c|}
\hline Code & $\begin{array}{l}\text { Name of section / } \\
\text { chapter }\end{array}$ & $\mathbf{2 0 1 0}$ & $\mathbf{2 0 1 1}$ & $\mathbf{2 0 1 2}$ & $\mathbf{2 0 1 3}$ & $\mathbf{2 0 1 4}$ & $\mathbf{2 0 1 5}$ & $\mathbf{2 0 1 6}$ & $\mathbf{2 0 1 7}$ \\
\hline & Total export & 1541.5 & 2216.8 & 2161.9 & 2428.3 & 2339.5 & 1966.8 & 2044.6 & 2425.0 \\
\hline I & $\begin{array}{l}\text { Live animals; } \\
\text { animal products }\end{array}$ & 27.0 & 38.0 & 37.8 & 37.2 & 59.7 & 37.5 & 40.2 & 47.1 \\
\hline II & $\begin{array}{l}\text { Vegetable products } \\
\text { III }\end{array}$ & 340.7 & 471.0 & 360.5 & 507.0 & 549.7 & 501.7 & 529.5 & 662.5 \\
\hline $\begin{array}{l}\text { Animal or } \\
\text { vegetable fats and } \\
\text { oils and their } \\
\text { cleavage products; } \\
\text { prepared edible } \\
\text { fats; animal or } \\
\text { vegetable waxes }\end{array}$ & 47.6 & 77.5 & 89.7 & 44.0 & 77.5 & 72.0 & 54.3 & 53.7 \\
\hline IV & $\begin{array}{l}\text { Prepared } \\
\text { foodstuffs; } \\
\text { beverages, spirits } \\
\text { and vinegar; } \\
\text { tobacco and } \\
\text { manufactured } \\
\text { tobacco substitutes }\end{array}$ & 316.9 & 330.6 & 390.9 & 427.3 & 378.4 & 303.3 & 321.5 & 367.7 \\
\hline Agri-food products & 732.2 & 917.1 & 878.9 & 1015.5 & 1065.4 & 914.5 & 945.5 & 1131.0 \\
\hline Share in export, \% & 47.50 & 41.37 & 40.65 & 41.82 & 45.54 & 46.50 & 46.24 & 46.64 \\
\hline
\end{tabular}

Source: Elaborated by the author based on the data of the National Bureau of Statistics.

\section{Re-export}

Re-export accounts for a significant share of the total value of goods exported by the Republic of Moldova. If in 2011 the re-export share in the total export constituted $45.18 \%$, this indicator gradually decreased over the years, thus constituting $32.35 \%$ in 2017.

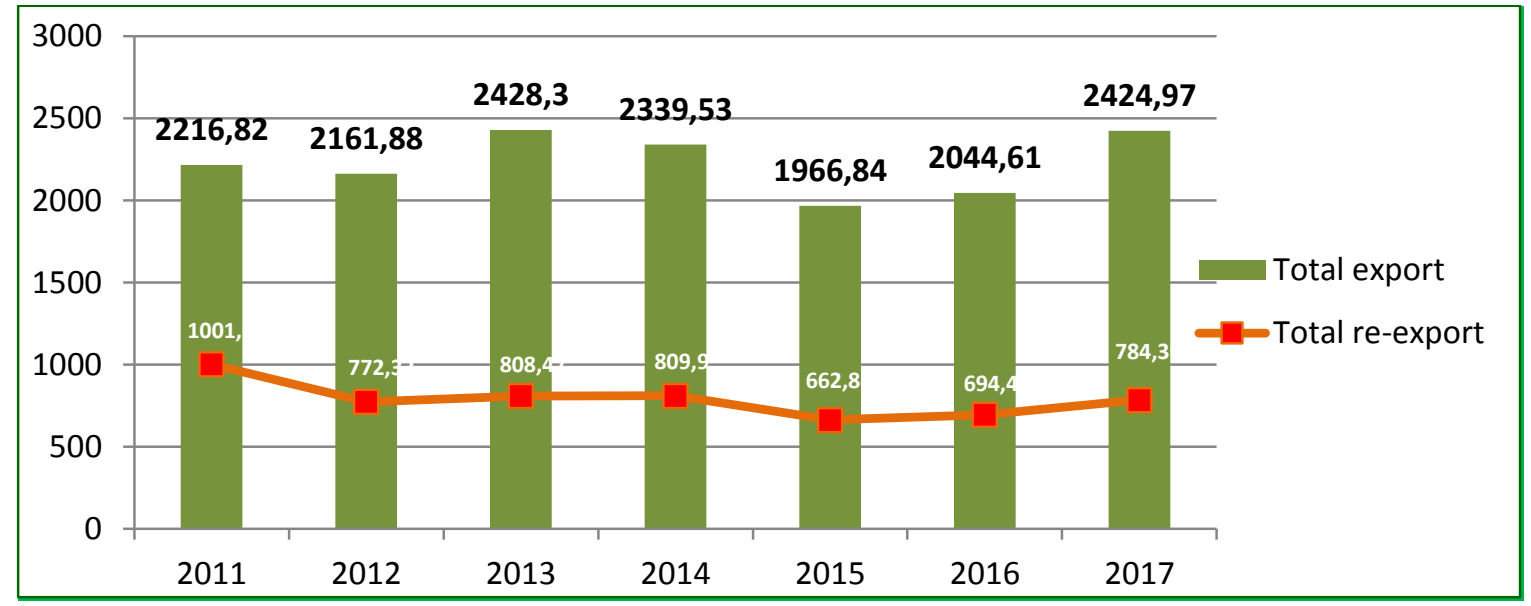

Figure 4. Total export and total re-export during 2011-2017, mil. USD

Source: World Bank, Wits database, www.wits.worldbank.org

No. $1 / 2019$ 
The most significant groups of goods with a larger share of total re-exports are the following ones:

- "Textiles and textile articles", which over the years 2011-2017 had a share of approximately $31 \%$, with an increase of up to $38.3 \%$ in 2017 . Within this group, the largest re-exports are registered under the headings "Articles of apparel and clothing accessories, knitted or crocheted", "Articles of apparel and clothing accessories, not knitted or crocheted" and "Knitted or crocheted fabrics", which in turn have a coverage of $89.12 \%$ of the total group for the year 2017. The main partner countries in the re-export chapter are Italy, the United Kingdom, Romania and Turkey.

- "Machinery and mechanical appliances; electrical equipment; parts thereof; sound recorders and reproducers, television image and sound recorders and reproducers, and parts and accessories of such articles", which in 2012 accounting for $10.65 \%$ of total re-exports had a steady increase in 2017 with a share of $23.14 \%$. Within the group, the most significant re-exports are carried out within the chapters: "Machinery and mechanical appliances; electrical equipment; parts thereof; sound recorders and reproducers, television image and sound recorders and reproducers, and parts and accessories of such articles" and "Nuclear reactors, boilers, machinery and mechanical appliances; parts thereof" which hold the total number of re-exports in the total for the given group for the year 2017. The main re-export countries are: Romania, Bulgaria, Germany, Russia and Italy.

- "Products of the chemical or allied industries" in the period 2012-2015 held a share of about $16 \%$, with a reduction to $8.9 \%$ in 2017 . This share is due to the re-export of "Pharmaceutical products", "Soap, organic surface-active agents, washing preparations, lubricating preparations, artificial waxes, prepared waxes, polishing or scouring preparations, candles and similar articles, modelling pastes, 'dental waxes' and dental preparations with a basis of plaster" and "Essential oils and resinoids; perfumery, cosmetic or toilet preparations", which account for $95.3 \%$ of the total value of the re-exported products in the given group for the year 2017. The main re-export partners of the given group are: Russian Federation, Ukraine, Kazakhstan, Poland and Georgia.

- "Miscellaneous manufactured articles" has a floating quota during 2011-2017, with 8\% in 2011 and $5.6 \%$ in 2017 of all re-exported products. In 2017, the re-export of this group is entirely due to the categories of goods "Toys, games, and sports requisites; parts and accessories thereof" and "Miscellaneous articles", the main partners being the Netherlands, Germany, Romania, the Russian Federation and the Czech Republic.

- "Prepared foodstuffs; beverages, spirits and vinegar; tobacco and manufactured tobacco substitutes". This group had a share of only $0.42 \%$ in 2011, then with different growth rates recorded a $4.4 \%$ share in 2017. Maintaining this quota is due to the categories of goods "Beverages, liquids alcohol and vinegar" and "Tobacco and manufactured tobacco substitutes", which together constitute $91.55 \%$ of the total re-export of the given group for the year 2017.

Table 7

Re-export of the Republic of Moldova divided by groups of goods, 2016-2017

\begin{tabular}{|c|c|c|c|c|c|c|}
\hline \multirow{2}{*}{ Code } & \multirow{2}{*}{ Group name } & \multicolumn{2}{|r|}{2017} & \multicolumn{2}{|c|}{ Structure \% } & \multirow{2}{*}{$\begin{array}{l}\text { Structural } \\
\text { changes, } \\
\text { p.p. }\end{array}$} \\
\hline & & mil. USD & $\%$ to previous year & 2016 & 2017 & \\
\hline I & Live animals; animal products & 0.002 & 56.5 & 0.0005 & 0.0003 & -0.0003 \\
\hline II & Vegetable products & 21.8 & 99.7 & 3.1 & 2.7 & -0.3 \\
\hline III & $\begin{array}{l}\text { Animal or vegetable fats and oils } \\
\text { and their cleavage products; } \\
\text { prepared edible fats; animal or } \\
\text { vegetable waxes }\end{array}$ & 1.3 & 137.8 & 0.1 & 0.2 & 0.03 \\
\hline IV & $\begin{array}{l}\text { Prepared foodstuffs; beverages, } \\
\text { spirits and vinegar; tobacco and } \\
\text { manufactured tobacco } \\
\text { substitutes }\end{array}$ & 35.2 & 130.1 & 3.8 & 4.5 & 0.5 \\
\hline $\mathrm{V}$ & Mineral products & 17.3 & 291.5 & 0.8 & 2.2 & 1.3 \\
\hline VI & $\begin{array}{l}\text { Products of the chemical or } \\
\text { allied industries }\end{array}$ & 70.1 & 103.8 & 9.7 & 8.9 & -0.7 \\
\hline
\end{tabular}

No. $1 / 2019$ 


\begin{tabular}{|c|c|c|c|c|c|c|}
\hline \multirow{2}{*}{ Code } & \multirow{2}{*}{ Group name } & \multicolumn{2}{|r|}{2017} & \multicolumn{2}{|c|}{ Structure \% } & \multirow{2}{*}{$\begin{array}{l}\text { Structural } \\
\text { changes, } \\
\text { p.p. }\end{array}$} \\
\hline & & mil. USD & $\%$ to previous year & 2016 & 2017 & \\
\hline VII & $\begin{array}{l}\text { Plastics and articles thereof; } \\
\text { rubber and articles thereof }\end{array}$ & 13.1 & 58.5 & 3.2 & 1.6 & -1.5 \\
\hline VIII & $\begin{array}{l}\text { Raw hides and skins, leather, } \\
\text { furskins and articles thereof; } \\
\text { saddlery and harness; travel } \\
\text { goods, handbags and similar } \\
\text { containers; articles of animal } \\
\text { gut (other than silkworm gut) }\end{array}$ & 16.7 & 83.8 & 2.8 & 2.1 & -0.7 \\
\hline IX & $\begin{array}{l}\text { Wood and articles of wood; } \\
\text { wood charcoal; cork and articles } \\
\text { of cork; manufactures of straw, } \\
\text { of esparto or of other plaiting } \\
\text { materials; basketware and } \\
\text { wickerwork }\end{array}$ & 2.1 & 96.1 & 0.3 & 0.3 & -0.04 \\
\hline $\mathrm{X}$ & $\begin{array}{l}\text { Pulp of wood or of other fibrous } \\
\text { cellulosic material; waste and } \\
\text { scrap of paper or paperboard; } \\
\text { paper and paperboard and } \\
\text { articles thereof }\end{array}$ & 4.3 & 107.9 & 0.5 & 0.5 & -0.02 \\
\hline $\mathrm{XI}$ & Textiles and textile articles & 300.6 & 111.6 & 38.8 & 38.3 & -0.4 \\
\hline XII & $\begin{array}{l}\text { Footwear, headgear, umbrellas, } \\
\text { sun umbrellas, walking-sticks, } \\
\text { seat-sticks, whips, riding-crops } \\
\text { and parts thereof; prepared } \\
\text { feathers and articles made } \\
\text { therewith; artificial flowers; } \\
\text { articles of human hair }\end{array}$ & 25.6 & 111.8 & 3.3 & 3.2 & -0.03 \\
\hline XIII & $\begin{array}{l}\text { Articles of stone, plaster, } \\
\text { cement, asbestos, mica or } \\
\text { similar materials; ceramic } \\
\text { products; glass and glassware }\end{array}$ & 0.9 & 108.8 & 0.1 & 0.1 & -0.004 \\
\hline XIV & $\begin{array}{l}\text { Natural or cultured pearls, } \\
\text { precious or semi-precious } \\
\text { stones, precious metals, metals } \\
\text { clad with precious metal and } \\
\text { articles thereof; imitation } \\
\text { jewellery; coin }\end{array}$ & 0.3 & 159.7 & 0.02 & 0.03 & 0.01 \\
\hline XV & $\begin{array}{l}\text { Base metals and articles of base } \\
\text { metal }\end{array}$ & 19.4 & 89.7 & 3.1 & 2.4 & -0.6 \\
\hline XVI & $\begin{array}{l}\text { Machinery and mechanical } \\
\text { appliances; } \\
\text { equipment; parts thereof; sound } \\
\text { recorders and reproducers, } \\
\text { television image and sound } \\
\text { recorders and reproducers, and } \\
\text { parts and accessories of such } \\
\text { articles }\end{array}$ & 181.5 & 132.1 & 19.8 & 23.1 & 3.3 \\
\hline XVII & $\begin{array}{l}\text { Vehicles, aircraft, vessels and } \\
\text { associated transport equipment }\end{array}$ & 21.0 & 91.5 & 3.3 & 2.6 & -0.6 \\
\hline XVII & $\begin{array}{l}\text { Optical, photographic, } \\
\text { cinematographic, measuring, } \\
\text { checking, precision, medical or } \\
\text { surgical instruments and } \\
\text { apparatus; clocks and watches; }\end{array}$ & 9.1 & 168.7 & 0.7 & 1.2 & 0.4 \\
\hline
\end{tabular}




\begin{tabular}{|c|l|c|c|c|c|c|}
\hline \multirow{2}{*}{ Code } & \multicolumn{1}{|c|}{ Group name } & mil. USD & \% to previous year & $\mathbf{2 0 1 6}$ & $\mathbf{2 0 1 7}$ & $\begin{array}{c}\text { Structure } \\
\text { changes, } \\
\text { p.p. }\end{array}$ \\
\hline & $\begin{array}{l}\text { musical instruments; parts and } \\
\text { accessories thereof }\end{array}$ & & & & & \\
\hline XX & $\begin{array}{l}\text { Miscellaneous manufactured } \\
\text { articles }\end{array}$ & 44.1 & 106.7 & 5.9 & 5.6 & -0.3 \\
\hline XXI & $\begin{array}{l}\text { Works of art, collectors pieces } \\
\text { and antiques }\end{array}$ & 0.01 & 1.6 & 0.1 & 0.001 & -0.1 \\
\hline \multicolumn{1}{|c|}{ Total } & $\mathbf{7 8 4 . 4}$ & $\mathbf{1 1 2 . 9}$ & $\mathbf{1 0 0}$ & $\mathbf{1 0 0}$ & $\mathbf{X}$ \\
\hline
\end{tabular}

Source: World Bank, Wits database, www.wits.worldbank.org

\section{Evaluation of physical volumes and average prices of import and export}

In order to analyze average prices and physical volumes, the price index and the physical volume index, which are calculated using Laspeyres formulas, are used. For the calculation of the indices using Laspeyres formulas, the monetary value of the goods and their physical volumes are required both, in the reference year and in the base year (Ceban, A. 2017). In the current analysis, the base year will be considered the year 2016 .

$$
\begin{gathered}
I_{P}=\frac{\sum p_{1} q_{0}}{\sum p_{0} q_{0}} \\
I_{q}=\frac{\sum p_{0} q_{1}}{\sum p_{0} q_{0}}
\end{gathered}
$$

where:

$I_{P}$ - price index

$I_{q}$ - physical volume index

As a result of the analysis of the physical volume and the average export prices, in 2017 it is noted an increase of the physical volume by $11.9 \%$ and a decrease of the average price indices by $11.7 \%$.

Table 8

\begin{tabular}{|c|c|c|c|c|c|c|}
\hline \multirow[b]{2}{*}{ No.Gr. } & \multirow[b]{2}{*}{ Main groups } & 2016 & 2017 & \multirow{2}{*}{$\begin{array}{l}\text { Sum } \\
\text { ration } \\
\%\end{array}$} & \multirow{2}{*}{$\begin{array}{l}\text { Average } \\
\text { price } \\
\text { index } \%\end{array}$} & \multirow{2}{*}{$\begin{array}{l}\text { Physical } \\
\text { volume } \\
\text { index \% }\end{array}$} \\
\hline & & $\begin{array}{l}\text { Sum, thous. } \\
\text { USD }\end{array}$ & $\begin{array}{l}\text { Sum, thous. } \\
\text { USD }\end{array}$ & & & \\
\hline I & Live animals; animal products & 40066.8 & 47047.6 & 117.4 & 111.6 & 108.6 \\
\hline II & Vegetable products & 529467.3 & 662470.9 & 125.1 & 105.8 & 118.9 \\
\hline III & $\begin{array}{l}\text { Animal or vegetable fats and oils and } \\
\text { their cleavage products; prepared } \\
\text { edible fats; animal or vegetable } \\
\text { waxes }\end{array}$ & 54289.7 & 53713.4 & 98.9 & 89.3 & 111.2 \\
\hline IV & $\begin{array}{l}\text { Prepared foodstuffs; beverages, } \\
\text { spirits and vinegar; tobacco and } \\
\text { manufactured tobacco substitutes }\end{array}$ & 321527.2 & 367728.2 & 114.3 & 115.7 & 100.6 \\
\hline $\mathrm{V}$ & Mineral products & 14118.8 & 28691.4 & 203.2 & 107.7 & 188.0 \\
\hline VI & $\begin{array}{l}\text { Products of the chemical or allied } \\
\text { industries }\end{array}$ & 90032.2 & 98672.6 & 109.6 & 107.7 & 112.5 \\
\hline VII & $\begin{array}{l}\text { Plastics and articles thereof; rubber } \\
\text { and articles thereof }\end{array}$ & 35613.4 & 33414.8 & 93.8 & 95.8 & 101.6 \\
\hline VIII & $\begin{array}{l}\text { Raw hides and skins, leather, } \\
\text { furskins and articles thereof; } \\
\text { saddlery and harness; travel goods, } \\
\text { handbags and similar containers; }\end{array}$ & 23929.3 & 20850.4 & 87.1 & 110.8 & 98.9 \\
\hline
\end{tabular}

Average price index and physical volume index of export by commodity groups in 2017 


\begin{tabular}{|c|c|c|c|c|c|c|}
\hline \multirow[b]{2}{*}{ No.Gr. } & \multirow[b]{2}{*}{ Main groups } & \multirow{2}{*}{$\begin{array}{l}\quad 2016 \\
\text { Sum, thous. } \\
\text { USD }\end{array}$} & \multirow{2}{*}{$\begin{array}{l}\quad 2017 \\
\text { Sum, thous. } \\
\text { USD }\end{array}$} & \multirow{2}{*}{$\begin{array}{l}\text { Sum } \\
\text { ration } \\
\%\end{array}$} & \multirow{2}{*}{$\begin{array}{l}\text { Average } \\
\text { price } \\
\text { index \% }\end{array}$} & \multirow{2}{*}{$\begin{array}{l}\text { Physical } \\
\text { volume } \\
\text { index \% }\end{array}$} \\
\hline & & & & & & \\
\hline & $\begin{array}{l}\text { articles of animal gut (other than } \\
\text { silkworm gut) }\end{array}$ & & & & & \\
\hline IX & $\begin{array}{l}\text { Wood and articles of wood; wood } \\
\text { charcoal; cork and articles of cork; } \\
\text { manufactures of straw, of esparto or } \\
\text { of other plaiting materials; } \\
\text { basketware and wickerwork }\end{array}$ & 8988.4 & 10519.7 & 117.0 & 102.9 & 131.2 \\
\hline $\mathrm{x}$ & $\begin{array}{l}\text { Pulp of wood or of other fibrous } \\
\text { cellulosic material; waste and scrap } \\
\text { of paper or paperboard; paper and } \\
\text { paperboard and articles thereof }\end{array}$ & 12192.2 & 13166.5 & 107.9 & 100.6 & 107.3 \\
\hline $\mathrm{XI}$ & Textiles and textile articles & 306897.9 & 346733.1 & 112.9 & 105.2 & 111.9 \\
\hline XII & $\begin{array}{l}\text { Footwear, headgear, umbrellas, sun } \\
\text { umbrellas, walking-sticks, seat- } \\
\text { sticks, whips, riding-crops and parts } \\
\text { thereof; prepared feathers and } \\
\text { articles made therewith; artificial } \\
\text { flowers; articles of human hair }\end{array}$ & 29345.9 & 33983.9 & 115.8 & 106.0 & 111.2 \\
\hline XIII & $\begin{array}{l}\text { Articles of stone, plaster, cement, } \\
\text { asbestos, mica or similar materials; } \\
\text { ceramic products; glass and } \\
\text { glassware }\end{array}$ & 44214.6 & 42059.5 & 95.1 & 110.4 & 88.4 \\
\hline XIV & $\begin{array}{l}\text { Natural or cultured pearls, precious } \\
\text { or semi-precious stones, precious } \\
\text { metals, metals clad with precious } \\
\text { metal and articles thereof; imitation } \\
\text { jewellery; coin }\end{array}$ & 758.1 & 1214.0 & 160.1 & 120.6 & 384.7 \\
\hline XV & $\begin{array}{l}\text { Base metals and articles of base } \\
\text { metal }\end{array}$ & 43193.4 & 48302.5 & 111.8 & 117.9 & 228.1 \\
\hline XVI & $\begin{array}{l}\text { Machinery and mechanical } \\
\text { appliances; electrical equipment; } \\
\text { parts thereof; sound recorders and } \\
\text { reproducers, television image and } \\
\text { sound recorders and reproducers, } \\
\text { and parts and accessories of such } \\
\text { articles }\end{array}$ & 296507.4 & 389635.9 & 131.4 & 106.0 & 222.3 \\
\hline XVII & $\begin{array}{l}\text { Vehicles, aircraft, vessels and } \\
\text { associated transport equipment }\end{array}$ & 27473.9 & 41392.6 & 150.6 & 136.9 & 95.5 \\
\hline XVIII & $\begin{array}{l}\text { Optical, photographic, } \\
\text { cinematographic, measuring, } \\
\text { checking, precision, medical or } \\
\text { surgical instruments and apparatus; } \\
\text { clocks and watches; musical } \\
\text { instruments; parts and accessories } \\
\text { thereof }\end{array}$ & 28787.8 & 30808.8 & 107.0 & 97.9 & 168.9 \\
\hline $\mathrm{xX}$ & Miscellaneous manufactured articles & 133804.0 & 154134.4 & 115.1 & 102.2 & 145.2 \\
\hline XXI & $\begin{array}{l}\text { Works of art, collectors pieces and } \\
\text { antiques }\end{array}$ & 12.1 & 3.5 & 28.9 & 100.0 & 345.2 \\
\hline & Total & 2041220.3 & 2424543.2 & 118.7 & 88.3 & 111.9 \\
\hline
\end{tabular}

Source: Elaborated by the author based on the National Bureau of Statistics data.

The most significant increases that influenced exports favourably in 2017 compared to 2016 were recorded in the following groups: "Vegetable products" with an increase in the physical volume index by $18.9 \%$, "Machinery and mechanical appliances; electrical equipment; parts thereof; sound 
recorders and reproducers, television image and sound recorders and reproducers, and parts and accessories of such articles" with an increase in the physical volume index of 2.2 times, "Prepared foodstuffs; beverages, spirits and vinegar; tobacco and manufactured tobacco substitutes" with an increase in the physical volume index $(+0.6 \%)$ had a significant increase in the average prices index $(+15.7 \%)$ which eventually brought a significant monetary value to the growth in exports, "Textiles and textile articles" contributed to the increase of exports by the combination of growth of the physical volume index by $11.9 \%$ and the increase of the average price index by $5.2 \%$ and "Miscellaneous manufactured articles" with a significant increase of the physical volume index by $45.2 \%$.

One can note that there are groups that have even higher physical volume indexes, such as "Natural or cultured pearls, precious or semi-precious stones, precious metals, metals clad with precious metal and articles thereof; imitation jewellery; coin" with an increase of 3.8 times or "Works of art, collectors pieces and antiques" - with an increase of 3.4 times, but their contribution to the share of exports is not so great in order to be taken into account (Table 7).

A negative contribution to exports had the groups "Raw hides and skins, leather, furskins and articles thereof; saddlery and harness; travel goods, handbags and similar containers; articles of animal gut (other than silkworm gut)" - with a reduction in physical volume by $1.1 \%$, "Plastics and articles thereof; rubber and articles thereof" - which even with a certain stability of the physical volume index $(+1.6 \%)$ had a $4.2 \%$ reduction in the average price index that eventually contributed negatively to the value of exports, "Articles of stone, plaster, cement, asbestos, mica or similar materials; ceramic products; glass and glassware" - with a reduction of the physical volume index by $11.6 \%$.

After analyzing the average price indices and the physical volume indices of imported products, we observe that both are growing, so the average price index recorded an increase of $9.6 \%$ and the physical volume index by $21.4 \%$ compared to the previous year.

Table 9

Average price index and physical volume index of imported goods by group of goods in 2017

\begin{tabular}{|c|c|c|c|c|c|c|}
\hline \multirow{2}{*}{ No.Gr. } & \multirow{2}{*}{ Main groups } & 2016 & 2017 & \multirow{2}{*}{$\begin{array}{l}\text { Sum } \\
\text { ration } \\
\%\end{array}$} & \multirow{2}{*}{$\begin{array}{l}\text { Average } \\
\text { price } \\
\text { index } \%\end{array}$} & \multirow{2}{*}{$\begin{array}{l}\text { Physical } \\
\text { volume } \\
\text { index } \%\end{array}$} \\
\hline & & $\begin{array}{l}\text { Sum, thous. } \\
\text { USD }\end{array}$ & $\begin{array}{l}\text { Sum, thous. } \\
\text { USD }\end{array}$ & & & \\
\hline I & Live animals; animal products & 106834.9 & 131353.2 & 122.9 & 108.2 & 303.6 \\
\hline II & Vegetable products & 171622.5 & 195270.5 & 113.7 & 118.5 & 99.7 \\
\hline III & $\begin{array}{l}\text { Animal or vegetable fats and oils } \\
\text { and their cleavage products; } \\
\text { prepared edible fats; animal or } \\
\text { vegetable waxes }\end{array}$ & 24407.9 & 25735.1 & 105.4 & 103.2 & 102.5 \\
\hline IV & $\begin{array}{l}\text { Prepared foodstuffs; beverages, } \\
\text { spirits and vinegar; tobacco and } \\
\text { manufactured tobacco substitutes }\end{array}$ & 305176.1 & 352835.2 & 115.6 & 102.9 & 112.7 \\
\hline $\mathrm{V}$ & Mineral products & 630155.4 & 774172.7 & 122.8 & 109.0 & 115.8 \\
\hline VI & $\begin{array}{l}\text { Products of the chemical or allied } \\
\text { industries }\end{array}$ & 502630.1 & 573036.2 & 114.0 & 101.9 & 116.8 \\
\hline VII & $\begin{array}{l}\text { Plastics and articles thereof; rubber } \\
\text { and articles thereof }\end{array}$ & 257765.7 & 292148.4 & 113.3 & 105.4 & 107.6 \\
\hline VIII & $\begin{array}{l}\text { Raw hides and skins, leather, } \\
\text { furskins and articles thereof; } \\
\text { saddlery and harness; travel goods, } \\
\text { handbags and similar containers; } \\
\text { articles of animal gut (other than } \\
\text { silkworm gut) }\end{array}$ & 48294.8 & 64555.6 & 133.6 & 199.9 & 93.3 \\
\hline IX & $\begin{array}{l}\text { Wood and articles of wood; wood } \\
\text { charcoal; cork and articles of cork; } \\
\text { manufactures of straw, of esparto or }\end{array}$ & 85227.2 & 105797.8 & 124.1 & 107.4 & 116.2 \\
\hline
\end{tabular}




\begin{tabular}{|c|c|c|c|c|c|c|}
\hline \multirow{2}{*}{ No.Gr. } & \multirow{2}{*}{ Main groups } & 2016 & 2017 & \multirow{2}{*}{$\begin{array}{l}\text { Sum } \\
\text { ration } \\
\%\end{array}$} & \multirow{2}{*}{$\begin{array}{l}\text { Average } \\
\text { price } \\
\text { index } \%\end{array}$} & \multirow{2}{*}{$\begin{array}{l}\text { Physical } \\
\text { volume } \\
\text { index \% }\end{array}$} \\
\hline & & $\begin{array}{l}\text { Sum, thous. } \\
\text { USD }\end{array}$ & $\begin{array}{l}\text { Sum, thous. } \\
\text { USD }\end{array}$ & & & \\
\hline & $\begin{array}{l}\text { of other plaiting materials; } \\
\text { basketware and wickerwork }\end{array}$ & & & & & \\
\hline $\mathrm{X}$ & $\begin{array}{l}\text { Pulp of wood or of other fibrous } \\
\text { cellulosic material; waste and scrap } \\
\text { of paper or paperboard; paper and } \\
\text { paperboard and articles thereof }\end{array}$ & 78484.4 & 87973.3 & 112.1 & 99.2 & 113.9 \\
\hline $\mathrm{XI}$ & Textiles and textile articles & 345624.9 & 398272.4 & 115.2 & 108.7 & 108.1 \\
\hline XII & $\begin{array}{l}\text { Footwear, headgear, umbrellas, sun } \\
\text { umbrellas, walking-sticks, seat- } \\
\text { sticks, whips, riding-crops and parts } \\
\text { thereof; prepared feathers and } \\
\text { articles made therewith; artificial } \\
\text { flowers; articles of human hair }\end{array}$ & 27319.8 & 43942.5 & 160.8 & 126.6 & 129.8 \\
\hline XIII & $\begin{array}{l}\text { Articles of stone, plaster, cement, } \\
\text { asbestos, mica or similar materials; } \\
\text { ceramic products; glass and } \\
\text { glassware }\end{array}$ & 103715.5 & 122547.0 & 118.2 & 112.4 & 108.6 \\
\hline XIV & $\begin{array}{l}\text { Natural or cultured pearls, precious } \\
\text { or semi-precious stones, precious } \\
\text { metals, metals clad with precious } \\
\text { metal and articles thereof; imitation } \\
\text { jewellery; coin }\end{array}$ & 7360.2 & 8842.8 & 120.1 & 107.4 & 117.3 \\
\hline $\mathrm{XV}$ & $\begin{array}{l}\text { Base metals and articles of base } \\
\text { metal }\end{array}$ & 273872.1 & 343900.7 & 125.5 & 118.9 & 106.7 \\
\hline XVI & $\begin{array}{l}\text { Machinery and mechanical } \\
\text { appliances; electrical equipment; } \\
\text { parts thereof; sound recorders and } \\
\text { reproducers, television image and } \\
\text { sound recorders and reproducers, } \\
\text { and parts and accessories of such } \\
\text { articles }\end{array}$ & 643164.2 & 801208.0 & 124.5 & 113.6 & 117.5 \\
\hline XVII & $\begin{array}{l}\text { Vehicles, aircraft, vessels and } \\
\text { associated transport equipment }\end{array}$ & 232179.2 & 291810.7 & 125.6 & 104.3 & 122.9 \\
\hline XVIII & $\begin{array}{l}\text { Optical, photographic, } \\
\text { cinematographic, measuring, } \\
\text { checking, precision, medical or } \\
\text { surgical instruments and apparatus; } \\
\text { clocks and watches; musical } \\
\text { instruments; parts and accessories } \\
\text { thereof }\end{array}$ & 56743.2 & 76000.8 & 133.9 & 109.7 & 130.3 \\
\hline $\mathrm{XX}$ & $\begin{array}{l}\text { Miscellaneous } \\
\text { articles }\end{array}$ & 113813.0 & 135816.3 & 119.3 & 98.9 & 219.7 \\
\hline XXI & $\begin{array}{l}\text { Works of art, collectors pieces and } \\
\text { antiques }\end{array}$ & 4091.4 & 1143.0 & 27.9 & 117.7 & 31.3 \\
\hline & TOTAL & 4018482,8 & 4826362.7 & 120.1 & 109.6 & 121.4 \\
\hline
\end{tabular}

Source: Elaborated by the author based on the National Bureau of Statistics data.

Almost all product groups had a positive contribution to the increase in imports, the only exception is the group "Works of art, collectors pieces and antiques", which recorded a $68.7 \%$ decrease in the physical volume index and the group "Miscellaneous manufactured articles" that marked a decrease in the price index by $1.1 \%$ compared to 2016 . 
The most significant increase was influenced by imports from the following groups: "Machinery and mechanical appliances; electrical equipment; parts thereof; sound recorders and reproducers, television image and sound recorders and reproducers, and parts and accessories of such articles" which had both an increase in the average price index of $13.6 \%$ and the increase of the physical volume index by $17.5 \%$, "Mineral products" with an increase of the average price index by $9.0 \%$ and an increase of the physical volume index by $15.8 \%$, "Products of the chemical or allied industries" having an insignificant increase of the average price index by $1.9 \%$, however, with an increase in the physical volume index by $16.8 \%$, "Base metals and articles of base metal" with an increase of the average price index by $18.9 \%$ and of the physical volume index by $6.7 \%$ and "Vehicles, aircraft, vessels and associated transport equipment" with a small increase of the average price index by $4.3 \%$ and an increase of $22.9 \%$ of the physical volume index.

\section{Conclusions}

Together with the recovery of the foreign trade between 2015 and 2017 in terms of the volume of the years 2013-2014, exports have had higher revival rates than imports, thus keeping the influence degree at the same positions around the value $50 \%$.

At the same time, there is noted a growing reorientation of exports towards the European Union market, which is becoming more attractive for local producers, thus contributing to the systematic increase of the share of this market in the total exports. The quality issue is an important aspect that hinders the exports of goods of the country, due to the high standards established especially by EU countries, but this could represent a further motivation for Moldovan producers in order to manufacture quality goods with high added value. Nevertheless, there is considerably favourable the fact that export to "Other countries" is increasing, which has a positive impact on the diversification of new markets.

The most imported groups of commodities like "machinery and mechanical appliances, mineral products, products of the chemical industry, textiles and prepared foodstuffs; beverages, tobacco remain quite the same over the last years, due to the increase in consumption on the local market and the re-export of some categories of these products. On the other hand the export of vegetable products, electrical equipment, prepared foodstuffs, spirits and tobacco, as well as textiles are increasing due to the high values of investments, re-export, and oversupply of these goods on the domestic market.

The analysis carried out with the help of Laspeyres index allowed us to observe that even if the prices for goods from the imported commodity groups increased, the physical volume index also increased, thus showing the high dependence of the Republic of Moldova on the external market and lack of local products that could replace the imported ones.

\section{REFERENCES}

1. Biroul Național de Statistică al Republicii Moldova. [Accesat 15.10.2018]. Disponibil: www.statistica.md

2. CEBAN, Alexandru. Dynamics of the foreign trade of the Republic of Moldova in terms of Laspeyres indicators. In: Economy and Sociologie = Economy and Sociology. 2017, nr. 4, pp. 7182. ISSN 1857-4130.

3. Consumer price index manual: Theory and practice Geneva: International Labour Office. 2004. 566 p. ISBN 92-2-113699-X.

4. GANCIUCOV, Valentina, CEBAN, Alexandru. Evoluţia comerţului exterior în Republica Moldova în perioada 2007-2014. In: Analele Institutului Naţional de Cercetări Economice. Ediţia a V-a. Chişinău: Complexul Editorial INCE, 2015, nr. 1, pp. 47-58. ISSN 1857-3630, ISBN 978-99754326-6-5.

5. HELPMAN, Elhanan, KRUGMAN, Paul. Market structure and foreign trade: Increasing returns, imperfect competition, and the international economy. Cambridge: MIT press, 1985. 271 p. ISBN 0262081504.

6. POMFRET, R. Regional Trade Agreements. In: School of Economics Working Papers. University of Adelaide. 2005, no. 15, pp. 1-20. 
7. LIPSEY, Robert E., MOLINARI, Linda, KRAVIS, Irving. Measures of Prices and Price Competitiveness in International Trade in Manufactured Goods. International Economic Transactions: Issues in Measurement and Empirical Research. Chicago: University of Chicago Press, 1991, pp. 144-199. ISBN 0-226-35135-1. [Accesat 10.10.2018]. Disponibil: http://www.nber.org/chapters/c8430

8. STRATAN, Alexandru, CLIPA, Victoria. Regimurile preferenţiale de comerț: riscuri şi oportunităţi de dezvoltare a comerţului exterior al Republicii Moldova. In: Buletinul Ştiinţific al Universităţii de Stat „Bogdan Petriceicu Hasdeu” din Cahul. Seria Ştiinţe Economice. 2011, nr. 1 (5), pp. 15-27. ISSN 1857-2723.

9. GALBEN, Ilian. Eficientizarea comerţului exterior al Republicii Moldova. Chişinău: ULIM, 2012. 320 p. ISBN 978-9975-56-042-9

10. World Integrated Trade Solution. [Accesat 28.11.2018]. Disponibil: https://wits.worldbank.org/

Recommended for publication:05.03.2019 